\title{
Environmental endocrine disruptors promote invasion and metastasis of SK-N-SH human neuroblastoma cells
}

\author{
HAITAO ZHU ${ }^{1}$, JICUI ZHENG ${ }^{1}$, XIANMIN XIAO ${ }^{1}$, SHAN ZHENG ${ }^{1}$, \\ KUIRAN DONG ${ }^{1}$, JIANGBIN LIU ${ }^{1}$ and YANG WANG ${ }^{2}$ \\ ${ }^{1}$ Department of Surgery of Children's Hospital, ${ }^{2}$ Anatomy and Histology and Embryology \\ of Shanghai Medical School, Fudan University, Shanghai, P.R. China
}

Received August 6, 2009; Received September 9, 2009

DOI: $10.3892 /$ or_00000614

\begin{abstract}
Neuroblastoma (NB) is the most common pediatric extracranial cancer. Metastasis is the main cause of mortality in NB patients. Currently, little is known about the risk factors and their mechanisms that cause metastasis. Environmental endocrine disruptors (EED) are recently identified risk factors associated with various human diseases including malignant tumors. Our previous studies have implicated the role of di(2-ethylhexyl) phthalate (DEHP) and bisphenol A (BPA), two of the most common EED, in neuroblastoma cell proliferation. Here, we further investigated the effects of DEHP, BPA as well as 173 -estradiol $\left(\mathrm{E}_{2}\right)$ on the invasion and metastasis of human neuroblastoma SK-N-SH cells in vitro. SK-N$\mathrm{SH}$ cells expressed estrogen receptor (ER)- $\beta$, matrix metalloproteinases-2 (MMP-2), MMP-9 and tissue inhibitor of matrix metalloproteinase-2 (TIMP-2) at readily detectable levels. $50 \mu \mathrm{M}$ DEHP, $0.1 \mu \mathrm{M}$ BPA and $10 \mu \mathrm{M} \mathrm{E}_{2}$ exposure all resulted in enhanced motility and invasiveness of SK-N-SH cells $(\mathrm{P}<0.001)$, elevated expression of MMP-2 and MMP-9, and decreased expression of TIMP-2 $(\mathrm{P}<0.01)$. Furthermore, phosphorylation of Akt (Ser473) was also induced following the exposure $(\mathrm{P}<0.01)$. Importantly, both ER antagonist ICI182,780 and phosphoinositide 3-kinase (PI3K) specific inhibitor LY294002 significantly inhibited the DEHP, BPA, or $\mathrm{E}_{2}$-induced cell migration and invasion, as well as the disregulation of MMP-2, MMP-9 and TIMP-2 expression. ICI182,780 may have worked through abolishing Akt (Ser473) phosphorylation. In conclusion, DEHP, BPA, and
\end{abstract}

Correspondence to: Dr Xianmin Xiao, Department of Surgery, Children's Hospital, Fudan University, 399 Wanyuan Road, Shanghai 201102, P.R. China

E-mail:xmxiao@shmu.edu.cn

Key words: neuroblastoma, metastasis, di(2-ethylhexyl) phthalate, bisphenol A, 17ß-estradiol, matrix metalloproteinases, estrogen receptor, phosphoinositide 3-kinase pathway, protein serine/ threonine kinase
$\mathrm{E}_{2}$ potently promote invasion and metastasis of neuroblastoma cells through overexpression of MMP-2 and MMP-9 as well as downregulation of TIMP-2. ER-dependent pathway and PI3K/Akt pathway are involved, which may become potential therapeutic targets for neuroblastoma treatment.

\section{Introduction}

Neuroblastoma (NB) is one of the most frequent solid malignant tumors in children (1). NB affects around 10.5/10 million children younger than 15 years of age per year (2). It accounts for $7-10 \%$ of all malignacies of childhood and about $15 \%$ of all pediatric cancer deaths (2-5). However, little is known about the risk factors and their mechanisms involved in NB's etiopathogenesis. The prognosis for patients, particularly those with advanced stage disease, has remained poor despite great advances in clinical therapies occurred during the past few years $(2,3)$. Therefore, NB continues to be a great challenge to physicians as well as basic scientists.

Metastasis is the leading cause of death in neuroblastoma. It occurs in near $70 \%$ of NB patients at the time of primary diagnosis (6). Most patients with metastatic disease are currently classified into the high-risk group which has an overall survival rate less than $40 \%(3,4)$. Currently, the mechanisms of metastasis in NB are largely unknown. We believe exploring the risk factors involved in NB cell metastasis and understanding their mechanisms will contribute to improved preventive strategies and more effective treatments for this cancer.

Environmental endocrine disruptors (EED) are a large number of either natural or man-made exogenous compounds that have the potential to interfere with the normal endocrine system of the animals including human beings $(7,8)$. These chemicals are also called environmental estrogens or xenoestrogens since most of them mainly mimick the action of natural hormone estrogens such as 17ß-estradiol in the body. During past decades, with aggravation of global environmental problems, there have been growing concerns on relationships between daily exposure to environmental chemical contaminants including EED and human health. Accumulating evidence suggested that EED are causative factors for multiple human diseases including birth defects, 
developmental and metabolic disorders, reproductive disturbances, and malignant tumors (9-14). Children are especially susceptible to adverse effects of EED exposure due to their physiological characteristics such as small body size and limited capacity to metabolize EED $(9,10)$.

Di(2-ethylhexyl) phthalate (DEHP) and bisphenol A (BPA) are most common compounds in EED. They are widely used as plasticizers in most of plastic products including floor and wall coverings, food containers, blood storage bags, medical devices, baby bottles and children's toys $(7,15)$. Both animal experiments and epidemiological studies have shown harmful effects of exposure to DEHP or BPA on human health. Prenatal exposure to BPA induces neurobehavioral developmental disorders in mouse model (16). Morphological and functional alterations of both mouse and human reproductive system often occur after prenatal or adult exposure to DEHP or BPA (17-20). Higher BPA exposure is also associated with abnormal liver functions, cardiovascular diseases, diabetes and other metabolic disorders in human beings $(10,21)$. Furthermore, developmental exposure to DEHP or BPA also influence the promotion or progression of most common adult cancers, like breast cancer, prostate cancer and colon cancer $(13,22-23)$. It is of great interest to further investigate the relationship between DEHP or BPA exposure and pediatric solid malignant tumors including neuroblastoma due to children's susceptibility to these chemicals.

There are few reports concerning the relationship between environmental endocrine disruptors and neuroblastoma or other children solid malignant tumors. In our previous studies, we demonstrated that both DEHP and BPA had growth-promoting effect on neuroblastoma (24-26). In the present study, we further investigated whether these environmental endocrine chemicals as well as 17ß-estradiol $\left(\mathrm{E}_{2}\right)$ were also involved in SK-N-SH human neuroblastoma cell invasion and metastasis. We have also attempted to understand their mechanisms.

\section{Materials and methods}

Cell culture and treatment. SK-N-SH, a neuroblastoma cell line purchased from Shanghai Institute for Biological Sciences, Chinese Academy of Sciences, was cultured in Roswell Park Memorial Institute-1640 (RPMI-1640) medium (Sigma-Aldrich, St. Louis, MO) supplemented with $10 \%$ heat-inactivated fetal bovine serum (FBS; Biochrom, Berlin, Germany), $100 \mathrm{U} / \mathrm{ml}$ penicillin $\mathrm{G}, 100 \mu \mathrm{g} / \mathrm{ml}$ streptomycin, and $0.1 \mathrm{M} \mathrm{L-glutamine.} \mathrm{Cells} \mathrm{were} \mathrm{grown} \mathrm{in} \mathrm{a} \mathrm{humidified}$ atmosphere with $5 \% \mathrm{CO}_{2}$ in air at $37^{\circ} \mathrm{C}$. For steroid-depleted conditions, phenol red-free RPMI-1640 medium (SigmaAldrich) and 10\% charcoal-dextran-stripped FBS (cd-FBS; Biological Industries Ltd., Kibbutz Beit Haemek, Israel) were utilized for $48 \mathrm{~h}$ before experiments (25). MCF-7 human breast cancer cells, a gift from Dr Tiewei Chen of Cancer Hospital, Fudan University, were cultured in RPMI-1640 medium (Sigma-Aldrich) with 10\% FBS (Biochrom).

Chemicals. DEHP, BPA, and $\mathrm{E}_{2}$ were obtained from SigmaAldrich. Estrogen receptor (ER) antagonist ICI182,780 was purchased from Tocris (Bristol, UK) and phosphoinositide 3-kinase (PI3K) inhibitor LY294002 was obtained from Cell Signaling Technology (Beverly, MA). All reagents were dissolved in DMSO, and then diluted with the cell culture medium at the indicated concentrations. The final solvent concentration in the culture did not exceed $0.1 \%$.

Cell migration and invasion assay. Cell migration assay was performed using transwell cell culture chambers (Millipore, Bedford, MA) with 6.5-mm diameter polycarbonate filters (8 $\mu \mathrm{m}$ pore size). Each upper chamber was filled with $100 \mu 1$ cell suspension $\left(1 \times 10^{5} /\right.$ chamber $)$ that was prepared with $50 \mu \mathrm{M}$ DEHP, $0.1 \mu \mathrm{M}$ BPA, $10 \mu \mathrm{M} \mathrm{E}_{2}$ or solvent only with or without 1-h pretreatment of $10 \mu \mathrm{M}$ ICI182,780 or $20 \mu \mathrm{M}$ LY294002 in serum-free and phenol red-free RPMI-1640 medium. Each lower chamber was filled with $600 \mu 1$ phenol red-free RPMI-1640 medium supplemented with $10 \%$ cdFBS. After $16 \mathrm{~h}$, cells that had invaded the lower side of the filters were fixed with $4 \%$ paraformaldehyde followed by hematoxylin and eosin staining. The number of migrating cells was counted under a light microscope at a magnification of $\mathrm{x} 200$, and five random visual fields were selected for each examination.

For invasion assays, $50 \mu 1$ diluted 1:3 Matrigel (BD Biosciences, Bedford, MA) in serum-free cell culture medium was added to each upper chamber and incubated at $37^{\circ} \mathrm{C}$ for $2 \mathrm{~h}$ for gelling. Then the invasion assay procedure was the same as for the migration assay described above except that the incubation time of the experiment was $24 \mathrm{~h}$. Both experiments were repeated three times.

Reverse-transcriptase polymerase chain reaction ( $R T-P C R)$ and quantitative real-time PCR. The neuroblastoma cells were seeded in 60-mm dishes with phenol red-free RPMI1640 medium containing 10\% cd-FBS. After 24 h, cells were cultured in phenol red-free RPMI-1640 with 5\% cd-FBS overnight. Cells were further incubated for another $24 \mathrm{~h}$ in 5\% cd-FBS-supplemented medium with DEHP $(50 \mu \mathrm{M})$, BPA $(0.1 \mu \mathrm{M}), \mathrm{E}_{2}(10 \mu \mathrm{M})$, or solvent (control cells), with or without 1 -h pretreatment of ICI182,780 $(10 \mu \mathrm{M})$ or LY294002 $(20 \mu \mathrm{M})$. Total cellular RNA was then extracted using TRIzol Reagent (Invitrogen, Carlsbad, CA) following the protocol recommended by the manufacturer. Total RNA concentrations were measured by absorbance reading at $260 \mathrm{~nm}$ on a SmartSpec ${ }^{\mathrm{TM}}$ Plus spectrophotometer (BioRad, Hercules, CA). The purity of total RNA specimen was examined by determing the $\mathrm{A}_{260} / \mathrm{A}_{280}$ ratio. cDNA templates for use in PCR were synthesized from $0.5 \mu \mathrm{g}$ of total RNA by in vitro transcription in $10 \mu 1$ reaction containing $1 \mathrm{mM}$ dNTPs, $0.125 \mu \mathrm{M}$ oligo(dT), and $0.5 \mu \mathrm{l}$ of Avian Myeloblastosis Virus (AMV) reverse transcriptase (Takara Biotechnology, Dalian, China) at $42^{\circ} \mathrm{C}$ for $30 \mathrm{~min}$. RT-PCR reaction mixture including $2 \mu 1$ of cDNA templates from RT, $0.1 \mu \mathrm{M}$ of each primer, $5 \mu 15 \mathrm{X}$ PCR buffer, $2 \mu 1$ Takara Ex Taq HS (Takara Biotechnology), and sterile water in a reaction volume of $25 \mu \mathrm{l}$. Conditions for RT-PCR followed the manufacturer's protocol. The PCR products were then electrophoresed on a $1 \%$ agarose gel. For quantification, realtime PCR was performed and the reaction mixture including $1 \mu \mathrm{l}$ of cDNA, $0.2 \mu \mathrm{M}$ of each primer, $12.5 \mu 1 \mathrm{SYBR}^{\circledR}$ Premix Ex Taq ${ }^{\mathrm{TM}}$ (Takara Biotechnology), and sterile water 
Table I. Oligonucleotide sequences of primer pairs used for RT-PCR or quantitative real-time PCR.

\begin{tabular}{lllcc}
\hline Gene & \multicolumn{1}{c}{ Sense (5'-3') } & \multicolumn{1}{c}{ Antisense (5'-3') } & $\begin{array}{c}\text { Size } \\
(\text { bp })\end{array}$ & $\begin{array}{c}\text { Annealing } \\
\text { temperature }\left({ }^{\circ} \mathrm{C}\right)\end{array}$ \\
\hline ESR1 & CCC ACG GCC AGC AGG TGC CCT ACT AC & TCA CCC CTG CCC TCC CCA TCA TCT CT & 469 & 69 \\
ESR2 & AAT TGA CCA CCC CGG CAA GCT CAT CTT T & TGC CCT TGT TAC TCG CAT GCC TGA CG & 377 & 68 \\
MMP-2 & GCA AGC CCA AGT GGG ACA AGA A & AAA ACC GCA GTG GGG TCA CAT C & 135 & 60 \\
MMP-9 & GGA CGG GCT CCT GGC ACA C & GAG CGG CCC TCG AAG ATG AAG & 168 & 69 \\
TIMP-2 & AGG GCC AAA GCG GTC AGT GA & AGG AGG GGG CCG TGT AGA TAA ACT & 148 & 59 \\
GAPDH & GAA GGT GAA GGT CGG AGT C & GAA GGT GAA GGT CGG AGT C & 226 & 50 \\
\hline
\end{tabular}

in a reaction volume of $25 \mu 1$. The PCR conditions were $5 \mathrm{~min}$ at $94^{\circ} \mathrm{C}$ followed by 40 cycles at $94^{\circ} \mathrm{C}$ for $15 \mathrm{sec}$, $60^{\circ} \mathrm{C}$ for $15 \mathrm{sec}$, and $72^{\circ} \mathrm{C}$ for $20 \mathrm{sec}$. Experiments were carried out using the Rotor-Gene $3000^{\mathrm{TM}}$ system and rotor gene 6.1.90 detection software (Corbett Life Science, Sydney, Australia). The primer pairs for target genes including human estrogen receptor 1 (ESR1), estrogen receptor 2 (ESR2), matrix metallopeptidase (MMP)-2, MMP-9, and tissue inhibitor of metalloproteinase 2 (TIMP-2) were designed using DNAStar software (DNAStar, Inc., Madison, WI), and manufactured by Shanghai Invitrogen Biotechnology. All primer pairs were first tested by regular RT-PCR to be highly effective and specific for amplification. Primer sequences and annealing temperature are listed in Table I. GAPDH was used as the standard housekeeping gene. Ratios of target gene expression levels were calculated by subtracting the threshold cycle number $(\mathrm{Ct})$ of the target gene from the $\mathrm{Ct}$ of GAPDH. Ct values were defined as the number of PCR cycles at which the fluorescent signal during the PCR reaches a fixed threshold. Target gene expression was expressed relative to GAPDH gene expression. Then ratios of target gene expression between the treatment groups and the untreated group were also calculated. As a positive control, ESR 1 and ESR2 gene expression in both ER $\alpha$ and $\beta$ positive MCF-7 cells were also detected with the same RTPCR protocol described above (27). The whole experiments were repeated four times.

Immunocytochemistry. SK-N-SH cells were initially seeded at a density of $5 \times 10^{4}$ in 12 -well plate containing $0.01 \%$ polyL-lysine-coated glass slides. Growth medium was then removed, and the plate was rinsed with $0.01 \mathrm{M}$ phosphatebuffer solution (PBS, pH 7.2). Slides containing the attached cells were fixed in $4 \%$ paraformaldehyde in PBS for $15 \mathrm{~min}$ at room temperature. Cells were permeable for $15 \mathrm{~min}$ using $0.1 \%$ Triton X-100 in PBS, washed in PBS and then incubated in $5 \%$ normal goat serum (Boster, Wuhan, China) for $30 \mathrm{~min}$ at room temperature. After rinsing with PBS, cells were incubated with 5\% normal goat serum (negative control), anti-ER $\alpha$ (1:100 dilution, Thermo Fisher Scientific Inc., Fremont, CA), anti-ER $\beta$, anti-MMP-2, anti-MMP-9, and anti-TIMP-2 primary antibody (all 1:500 dilutions, Santa Cruz Biotechnology, Inc., Santa Cruz, CA) overnight at $4^{\circ} \mathrm{C}$. After being rinsed, cells were incubated with goat anti- rabbit/rabbit anti-mouse $\operatorname{IgG}(\mathrm{H}+\mathrm{L})$ conjugated to Oregon green (FITC) (Invitrogen) at a 1:1000 dilution and $1 \mu \mathrm{g} / \mathrm{ml}$ DAPI (Invitrogen) for $2 \mathrm{~h}$ at room temperature. Stained slides were coverslipped and visualized with an Olympus IX71 fluorescence microscope (Olympus Corp., Tokyo, Japan). As a positive control, the ER expression in MCF-7 cells was also detected with the same immuocytochemistry protocol described above.

Western blot analysis. Cells were treated with DEHP, BPA, $\mathrm{E}_{2}$, ICI182,780, or LY294002 as described for experimental conditions. After $24 \mathrm{~h}$, cells were collected in an appropriate

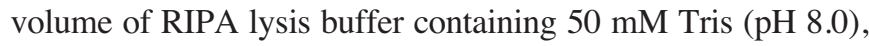
$1.0 \mathrm{mM}$ EDTA, $150 \mathrm{nM} \mathrm{NaCl}, 0.1 \%$ SDS, $1 \%$ Triton $\mathrm{X}-100$, $1 \%$ sodium deoxycholate, $2 \mathrm{mM} \mathrm{Na} \mathrm{VO}_{4}, 5 \mathrm{mM} \mathrm{NaF}$ and a protease inhibitor cocktail and incubated on ice for $30 \mathrm{~min}$ with occasional agitation. The suspension was then cleared by centrifugation at $20,000 \mathrm{~g}$ for $30 \mathrm{~min}$ at $4^{\circ} \mathrm{C}$ to yield supernatants comprising the total cell extract. Protein concentrations were determined using a BCA assay (Thermo Fisher Scientific Inc.). Protein extracts $(50-100 \mu \mathrm{g})$ were resolved by $6-8 \%$ SDS-polyacrylamide gels (SDS-PAGE) according to target protein sizes. After SDS-PAGE, the protein was then transferred onto polyvinylidene difluoride membranes (Millipore) at $300 \mathrm{~mA}$ for $2.5 \mathrm{~h}$. Membranes were blocked for $1 \mathrm{~h}$ in TBST [20 mM Tris-HCl (pH 7.6), $150 \mathrm{Mm} \mathrm{NaCl,} 0.05 \%$ Tween] containing 5\% non-fat dried milk and then incubated overnight at $4^{\circ} \mathrm{C}$ with the appropriate primary antibody: antiMMP-2, anti-MMP-9, anti-TIMP-2 (all 1:1000 dilutions; Santa Cruz Biotechnology Inc.); anti-Akt, anti-phospho-Akt (Ser473) (all 1:1000 dilutions; Cell Signaling Technology Inc.). After incubation for $3 \mathrm{~h}$ with goat anti-rabbit immunoglobulin G secondary antibodies (1:2000 dilution; Cell Signaling Technology Inc.) at room temperature, bands were visualized using an ECL chemiluminescence system (Millipore). Corresponding membranes were reprobed with anti-GAPDH antibody (1:2000 dilution; Abcam Inc., Cambridge, MA) to ensure equal loading of protein. The experiments were repeated three times.

Statistical analysis. Statistical analyses were performed using SPSS 13.0 statistical software (SPSS Inc., Chicago, IL). Data were expressed as mean \pm SEM. One-way analysis of variance (ANOVA) in conjunction with least significant 

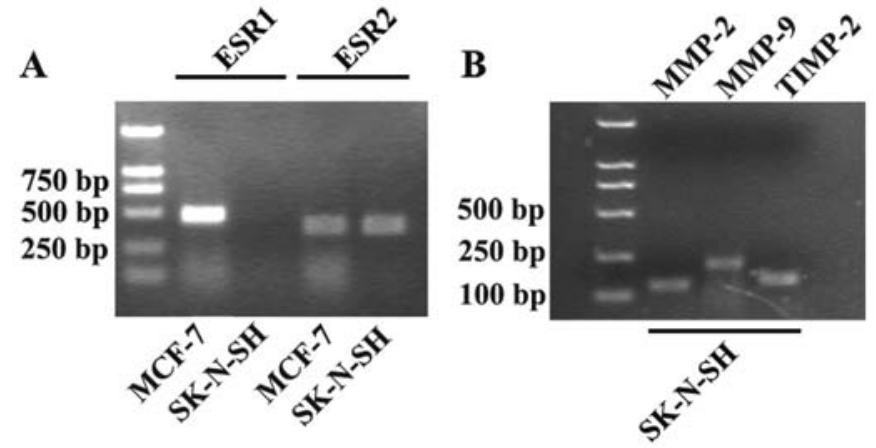

Figure 1. Estrogen receptor, MMP-2, MMP-9 and TIMP-2 gene mRNA expression in SK-N-SH cells detected by RT-PCR. (A) Expression of ESR1 and ESR2 which encode estrogen receptor (ER) $\alpha$ and $B$, respectively. Human breast cancer MCF-7 cells were used as the positive control. (B) MMP-2, MMP-9 and TIMP-2 mRNA expression in SK-N-SH cells.

difference test was performed to analyze experiments. The level of significance was set at $\mathrm{P}<0.05$.

\section{Results}

Estrogen receptors, MMP-2, MMP-9 and TIMP-2 expression in $S K-N$-SH cells. We examined the mRNA expression levels of MMP-2, MMP-9, TIMP-2 genes as well as estrogen receptor (ER) genes in SK-N-SH cells by regular RT-PCR. There was detectable expression of MMP-2, MMP-9, TIMP-2 genes as well as ESR2 gene encoding ERß protein in this cell line (Fig. 1). However, the expression of ESR1 gene encoding $\mathrm{ER} \alpha$ protein was negative in these cells (Fig. 1A). ERß, MMP-2, MMP-9 and TIMP-2 expression were further confirmed at protein level by immuocytochemistry (Figs. 2 and 3).

A
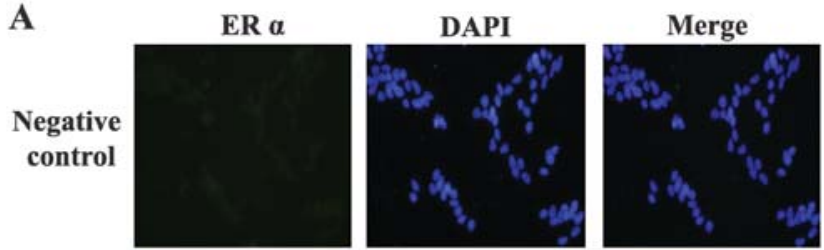

MCF-7
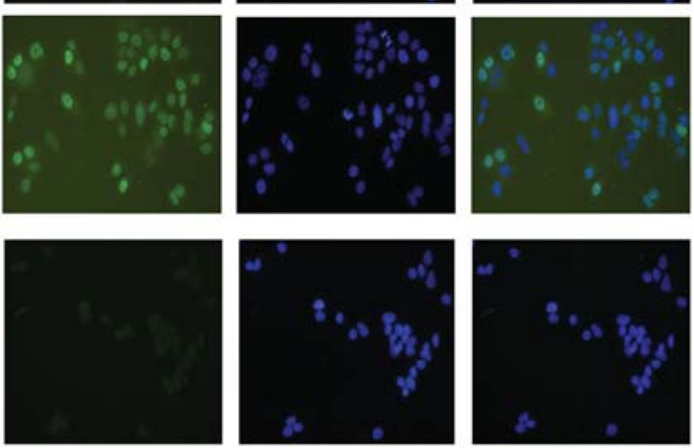

SK-N-SH

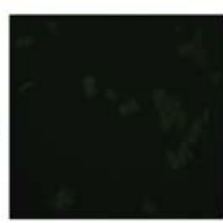

B
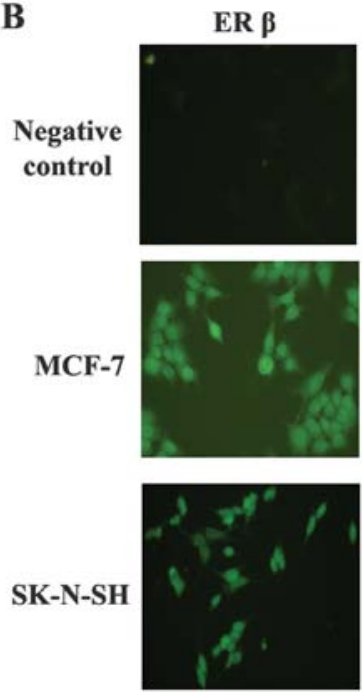

DAPI
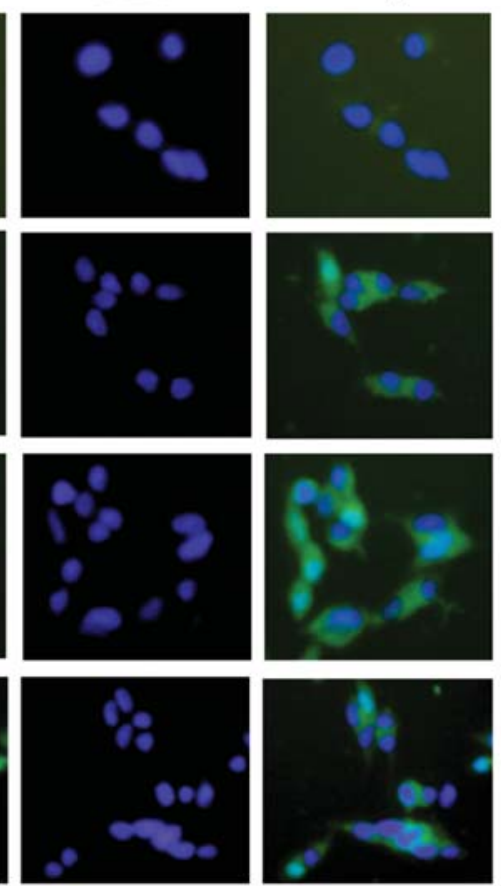

Figure 3. MMP-2, MMP-9 and TIMP-2 protein expression in SK-N-SH human neuroblastoma cells (original magnification, x200). MMP-2, MMP-9, or TIMP-2 protein (green), DAPI (blue).

DEHP, BPA or $E_{2}$ exposure enhances $S K-N$-SH cell migration and invasion. Based on a dose response experiment and our previous studies (24-26), the concentration of chemicals were determined: $50,0.1,10,10$ and $20 \mu \mathrm{M}$ was the concentration of DEHP, BPA, $\mathrm{E}_{2}$, ICI182,780 and LY294002 respectively used in the experiments.

Figure 2. The detection of estrogen receptor (ER) $\alpha$ and $\beta$ protein expression in SK-N-SH cells. The positive control in the experiment was human breast cancer MCF-7 cells which were previously identified to express both ER $\alpha$ and $\beta$ protein. (A) Detection of ER $\alpha$ protein expression in SK-N-SH cells (original magnification, x200). ER $\alpha$ (green), DAPI (blue). (B) Detection of ERß protein expression in SK-N-SH cells (original magnification, x200). ERß (green), DAPI (blue). 


\section{A}
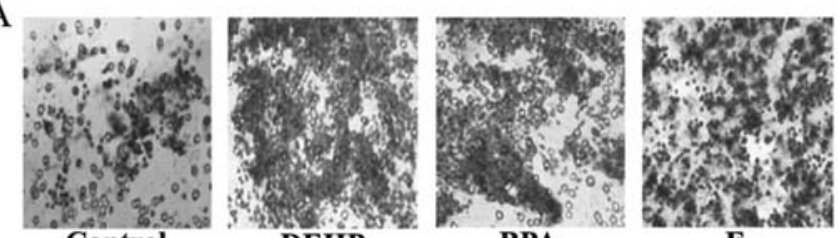

Control

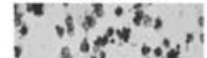

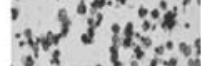
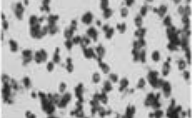

Control+ICI

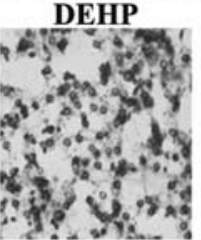

BPA


Control+LY

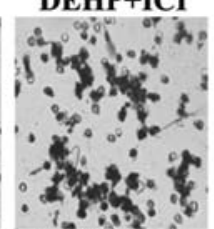

BPA+ICI

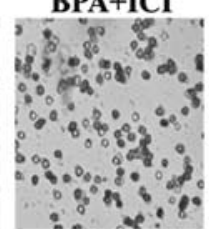

DEHP+LY

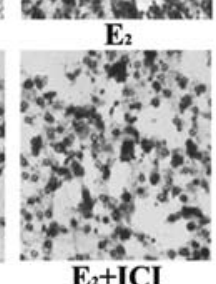

$\mathrm{E}_{2}+\mathrm{ICI}$

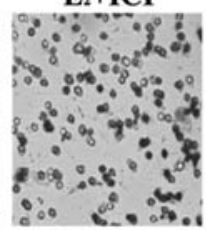

E2+LY

B

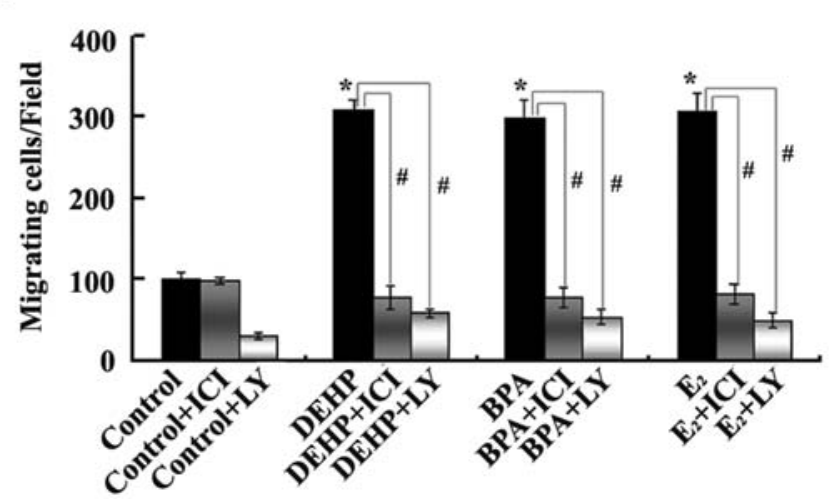

Figure 4. Migration assay in SK-N-SH cells after 16-h treatment. Cells were treated with DEHP $(50 \mu \mathrm{M})$, BPA $(0.1 \mu \mathrm{M}), \mathrm{E}_{2}(10 \mu \mathrm{M})$ or solvent only with or without pretreatment of estrogen receptor antagonist ICI182,780 (ICI, $10 \mu \mathrm{M}$ ) or PI3K specific inhibitor LY294002 (LY, $20 \mu \mathrm{M}$ ). (A) Representative images of SK-N-SH cells on the lower surface of the transwell membranes after 16-h treatment (original magnification, x200). (B) Quantitative comparison of migrating cells of different treatment groups. The number of migrated cells for each group was counted from 5 randomly selected microscopic fields (original magnification, x200). Quantitative data are presented as mean \pm SEM. $\left({ }^{*} \mathrm{P}<0.001\right.$, vs. the control group; ${ }^{\#} \mathrm{P}<0.001$, compared with the DEHP, BPA, or $\mathrm{E}_{2}$ group).

The cell migration and invasion assay were performed to investigate effects of DEHP, BPA, or $\mathrm{E}_{2}$ exposure on SK$\mathrm{N}-\mathrm{SH}$ human neuroblastoma cell migration and invasion in vitro. The changes in motility and invasiveness of SK-N-SH cells were observed 16 and $24 \mathrm{~h}$ post-exposure, respectively. The hematoxylin and eosin staining of migrating or invading cells through transwell filters suggested that the capacity of motility and invasiveness of cells in the DEHP, BPA or $\mathrm{E}_{2}$ group were much higher than those of control group (Figs. 4A and 5A). Compared to untreated cells $(100.80 \pm 8.93)$, the capacity of cell migration was significantly elevated by exposure to DEHP, BPA or $\mathrm{E}_{2}$

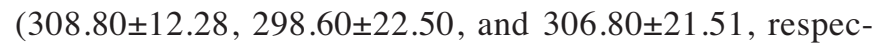
tively; $\mathrm{P}<0.001$; Fig. 4B, black columns). Moreover, the ability of cell invasion also significantly increased in the

A
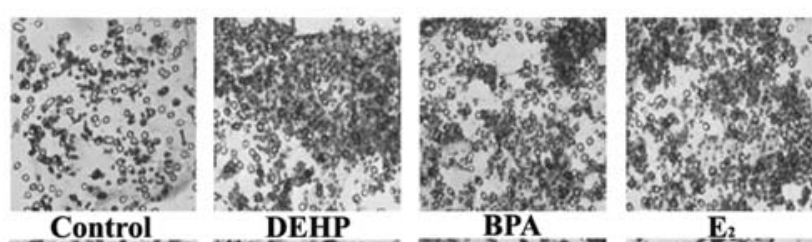

Control

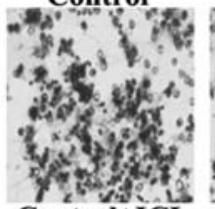

DEHP

BPA

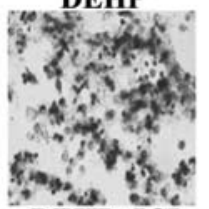

Control+ICI
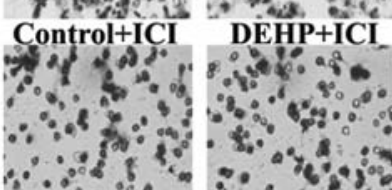

$\therefore: 300^{\circ}$

Control+LY

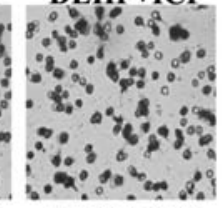

DEHP+LY
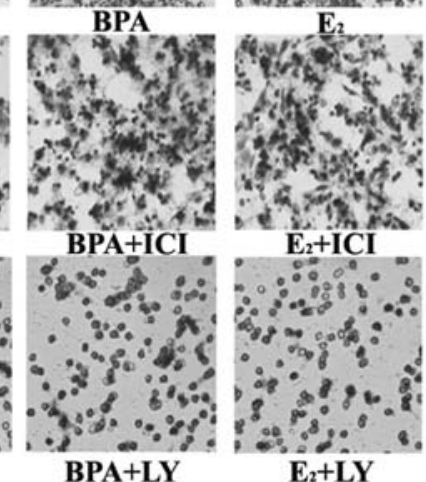

B

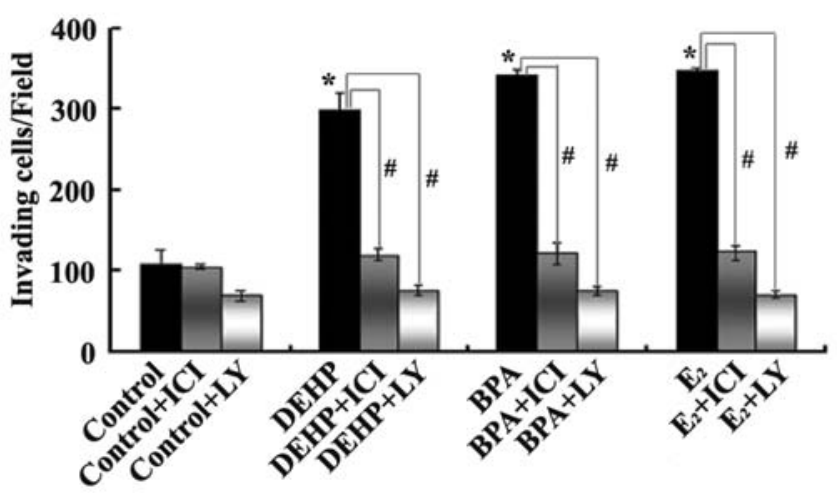

Figure 5. SK-N-SH cell invasion assay after 24-h treatment. Cells were treated with DEHP $(50 \mu \mathrm{M})$, BPA $(0.1 \mu \mathrm{M}), \mathrm{E}_{2}(10 \mu \mathrm{M})$ or solvent only with or without pretreatment of estrogen receptor antagonist ICI182,780 (ICI, $10 \mu \mathrm{M}$ ) or PI3K specific inhibitor LY294002 (LY, $20 \mu \mathrm{M}$ ). (A) Representative images of changes in SK-N-SH cell invasion capability after 24-h treatments (original magnification, x200). (B) Quantitative evaluation of invading cells of different treatment groups. The number of invaded cells for each group was counted from 5 randomly selected microscopic fields (original magnification, $\mathrm{x} 200$ ). Quantitative data are presented as mean \pm SEM. $\left({ }^{*} \mathrm{P}<0.001\right.$, vs. the control group; ${ }^{*} \mathrm{P}<0.001$, compared with the DEHP, $\mathrm{BPA}$, or $\mathrm{E}_{2}$ group).

DEHP, BPA or $\mathrm{E}_{2}$ group (298.60 $\pm 18.40,342.40 \pm 6.70$, and $347.60 \pm 3.90$, respectively) when compared with the control group (107.20 $\pm 18.40, \mathrm{P}<0.001$; Fig. 5B, black columns).

Exposure to DEHP, BPA or $E_{2}$ results in increased expression of MMP-2 and MMP-9 but a decrease in TIMP-2 expression. To further understand the effect of DEHP, BPA or $\mathrm{E}_{2}$ on SK-N-SH cell migration and invasion, quantitative real-time PCR and Western blotting were performed to detect mRNA and protein expression of MMP-2, MMP-9 and TIMP-2, which have been implicated in cell invasion and metastasis in neuroblastoma and other cancers $(28,29)$. Exposure to DEHP, BPA, or $\mathrm{E}_{2}$ for $24 \mathrm{~h}$ resulted in a significant increase in mRNA levels of both MMP-2 and MMP-9. Compared with the untreated group, the DEHP, BPA and $\mathrm{E}_{2}$ groups had (113.74 \pm 6.20$),(105.06 \pm 15.76)$ and $(94.21 \pm 21.03)$ 
A

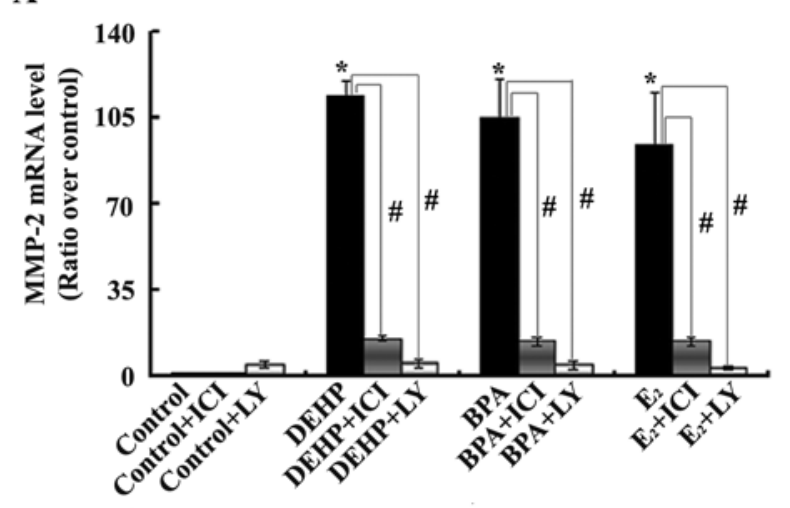

B

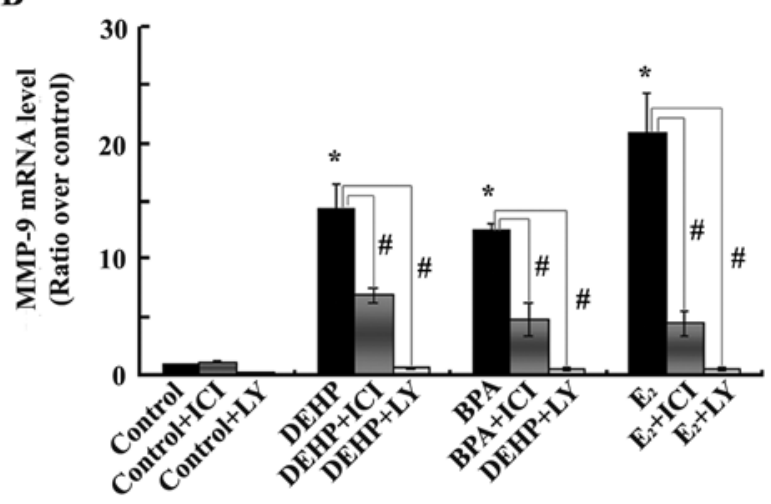

C

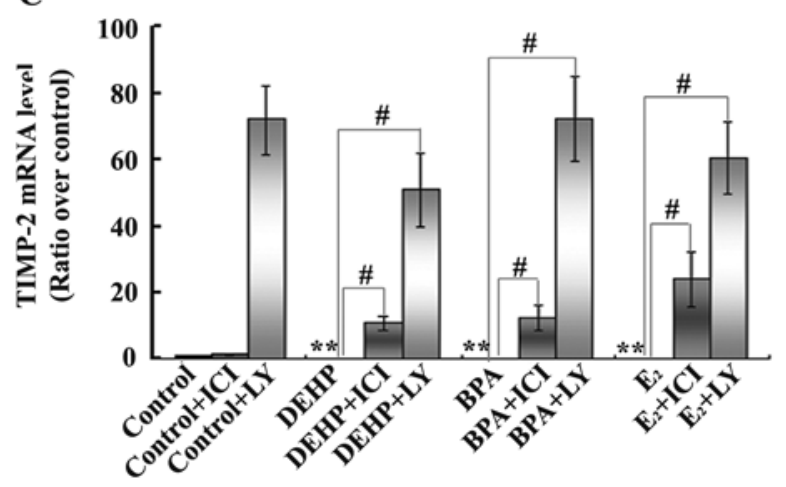

Figure 6. Quantification of MMP-2, MMP-9 and TIMP-2 gene mRNA expression in SK-N-SH cells after 24 drug treatments. Cells were treated with the indicated concentrations of DEHP, BPA or $\mathrm{E}_{2}$ with or without pretreatment of ICI182,780 (IC, $10 \mu \mathrm{M}$ ) or LY294002 (LY, $20 \mu \mathrm{M}$ ). Cells treated with solvent only were used as control. After $24 \mathrm{~h}$, the mRNA levels of MMP-2, MMP-9 and TIMP-2 mRNA in all groups were determined by quantitative real-time PCR. The mean mRNA expression in each group (normalized to GAPDH mRNA expression) was calculated. Then ratios of target gene expression between the drug treatment groups and the control group were also calculated. Quantitative data are presented as mean \pm SEM from four independent experiments. (A) MMP-2 mRNA expression in SK-N-SH cells with different treatments. (B) MMP-9 mRNA expression in SK-N-SH cells with different treatments. (C) TIMP-2 mRNA expression in SK-N-SH cells with different treatments. $\left({ }^{*} \mathrm{P}<0.001\right.$ compared to the control group; ${ }^{* *} \mathrm{P}<0.01$ compared with the control group; ${ }^{*} \mathrm{P}<0.001$ compared with the DEHP, BPA, or $\mathrm{E}_{2}$ group, respectively).

times higher MMP-2 mRNA expression respectively $(\mathrm{P}<0.001$; Fig. 6A, black columns). mRNA levels of MMP-9 in the DEHP, BPA and $\mathrm{E}_{2}$ groups were also respectively $(14.34 \pm 2.10),(12.44 \pm 0.73)$ and $(20.91 \pm 3.39)$ times higher than that in the control group $(\mathrm{P}<0.001$; Fig. 6B, black columns). On the contrary, a decrease in TIMP-2 mRNA expression was induced by DEHP, BPA, or $\mathrm{E}_{2}$ treatment. The DEHP, BPA and $\mathrm{E}_{2}$ groups respectively had 74, 65 and $88 \%$ lower TIMP-2 mRNA expression compared with the control group ( $\mathrm{P}<0.01$; Fig. $6 \mathrm{C}$, black columns). In addition, Western blot analysis showed MMP-2 protein expression as well as MMP-9 protein obviously increased in the DEHP, $\mathrm{BPA}$ and $\mathrm{E}_{2}$ groups $(1.348 \pm 0.035$ and $1.104 \pm 0.002$, $1.301 \pm 0.050$ and $1.223 \pm 0.010,1.485 \pm 0.040$ and $1.042 \pm 0.034$, respectively) compared with the untreated group $(0.545 \pm 0.014$ and $0.345 \pm 0.014 ; \mathrm{P}<0.01$, Fig. $7 \mathrm{~B}$ and $\mathrm{C}$, first 4 lanes and columns). But TIMP-2 protein expression significantly decreased in cells treated with DEHP, BPA or $\mathrm{E}_{2}(0.133 \pm 0.005$, $0.110 \pm 0.013$, and $0.174 \pm 0.005$, respectively) compared to untreated cells $(0.33 \pm 0.027 ; \mathrm{P}<0.05 ;$ Fig. $7 \mathrm{C}$, first 4 lanes and columns).

DEHP, BPA and $E_{2}$ induce phosphorylation of Akt (Ser473) in neuroblastoma cells. Western blot analyses of both Akt and phosphorylation of Akt (Ser473) protein were examined to further observe whether activation of PI3K/Akt signaling pathway was involved in promoting effects of DEHP, BPA or $\mathrm{E}_{2}$ on $\mathrm{SK}-\mathrm{N}-\mathrm{SH}$ cell migration and invasion. The basal level of phosphorylation of Akt (Ser473) apparently increased by treatment with DEHP, BPA or $\mathrm{E}_{2}$ (Fig. 8A and C). Densitometry analysis showed that phosphorylation levels of Akt (Ser473) in the DEHP and BPA groups were significantly higher than that in the control group $(2.176 \pm 0.065$ vs. $0.717 \pm 0.006$, and $2.337 \pm 0.037$ vs. $0.605 \pm 0.006$, respectively, $\mathrm{P}<0.01$; Fig. $8 \mathrm{~B}$ and $\mathrm{D})$. Phosphorylations of Akt (Ser473) was increased by 145 and $173 \%$ in DEHP and BPA-treated cells, respectively. A similar trend also occurred in the $\mathrm{E}_{2}$ group $(\mathrm{P}<0.01$, Fig. $8 \mathrm{~B}$ and $\mathrm{D})$. However, there were no significant change in Akt protein expression in any of the experimental groups ( $\mathrm{P}>0.05$, Fig. 8$)$.

ICI182,780 and LY294002 treatments both abolished the effect of DEHP, BPA and $E_{2}$ on the migration and invasion of $S K-N$-SH cells. Estrogen receptor (ER) dependent pathway is known to be involved in the estrogenic activities of environmental endocrine disruptors and estrogen (30-32). Therefore, ER antagonist ICI182,780 was applied to determine whether ER-dependent pathway was also involved in 
A

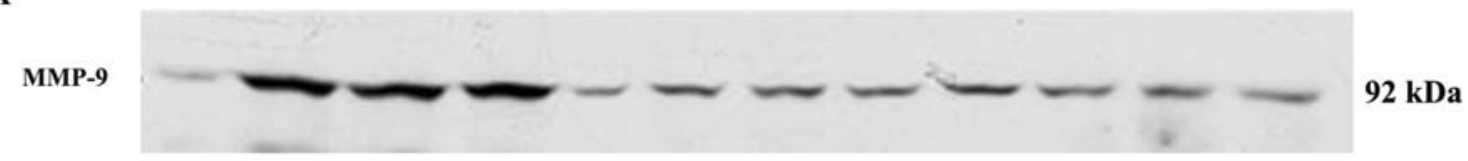

MMP-2 - V V

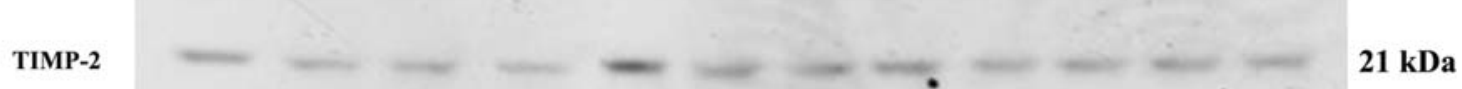

GAPDH CD 37 kDa
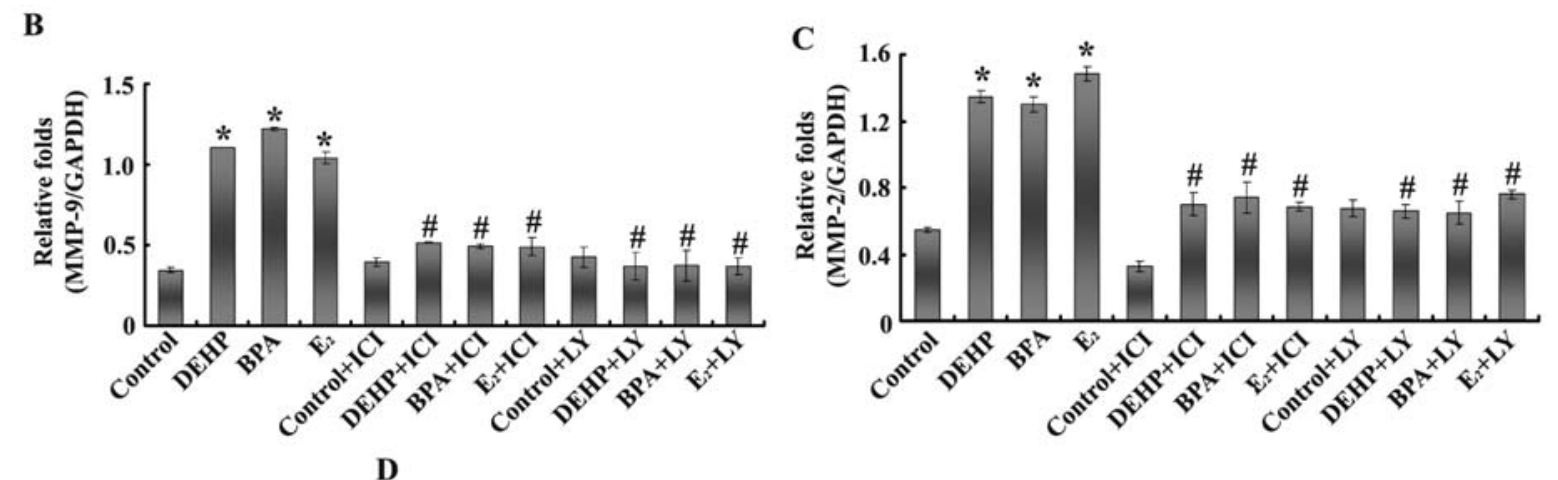

D

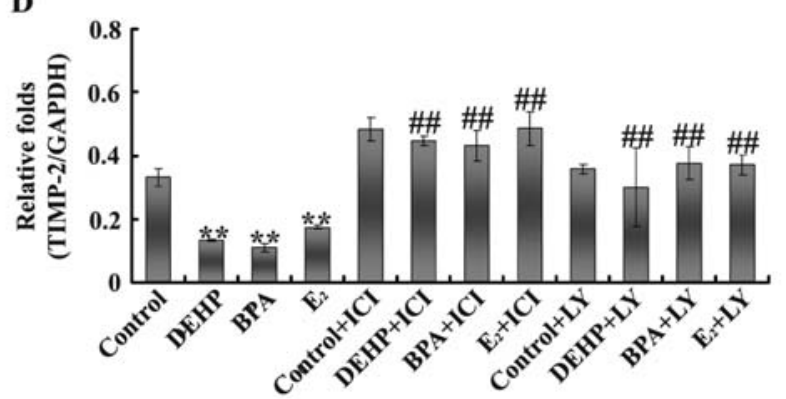

Figure 7. MMP-2, MMP-9, and TIMP-2 protein expression in human neuroblastoma SK-N-SH cells treated with DEHP, BPA, or E $\mathrm{E}_{2}$ with or without ICI182,780 (ICI, $10 \mu \mathrm{M})$ or LY294002 (LY, $20 \mu \mathrm{M})$ pretreatments. After $24 \mathrm{~h}$ drug treatments, Western blot analysis was performed to detect the change in expression of MMP-2, MMP-9, and TIMP-2 protein. Equal loading was confirmed by Western blotting probed with an anti-GAPDH antibody. The mean protein expression (normalized to GAPDH protein expression) in each group was calculated from three independent experiments. (A) Representative images of MMP-2, MMP-9 and TIMP-2 protein expression in different treatment groups. (B) Quantitative evaluation histograms of MMP-9 protein expression. (C) Quantitative evaluation histogram of MMP-2 protein expression. (D) Quantitative evaluation histogram of TIMP-2 protein expression. Data are presented as mean \pm SEM. $\left({ }^{*} \mathrm{P}<0.01\right.$, vs. the control group; ${ }^{\#} \mathrm{P}<0.01$, vs. the DEHP, BPA, or $\mathrm{E}_{2}$ group, respectively; ${ }^{* *} \mathrm{P}<0.05$, vs. the control group; ${ }^{* \#} \mathrm{P}<0.05$, vs. the DEHP, BPA, or $\mathrm{E}_{2}$ group, respectively).

the process of DEHP, BPA or $\mathrm{E}_{2}$ regulating cellular motility or invasiveness. PI3K specific inhibitor LY294002 was also used to investigate whether downregulation of PI3K pathway activity affects DEHP, BPA or E2-induced SK-N-SH cell migration or invasion.

In vitro cell migration assay showed that the capacity of cell migration in the groups pretreated with either ICI182,780 or LY294002 did not significantly increase when exposed

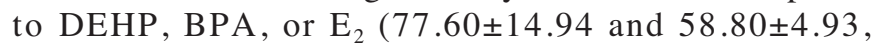
$79.00 \pm 11.85$ and $54.20 \pm 8.85,81.60 \pm 12.00$ and $50.00 \pm 8.04$, respectively) compared to those in the group treated with DEHP, BPA, or $\mathrm{E}_{2}$ only $(308.80 \pm 12.28,298.60 \pm 22.50$, and $306.80 \pm 21.51$, respectively; $\mathrm{P}<0.001$; Fig. $4 \mathrm{~A}$ and $\mathrm{B})$. Moreover, cells pretreated with ICI182,780 or LY294002 still 

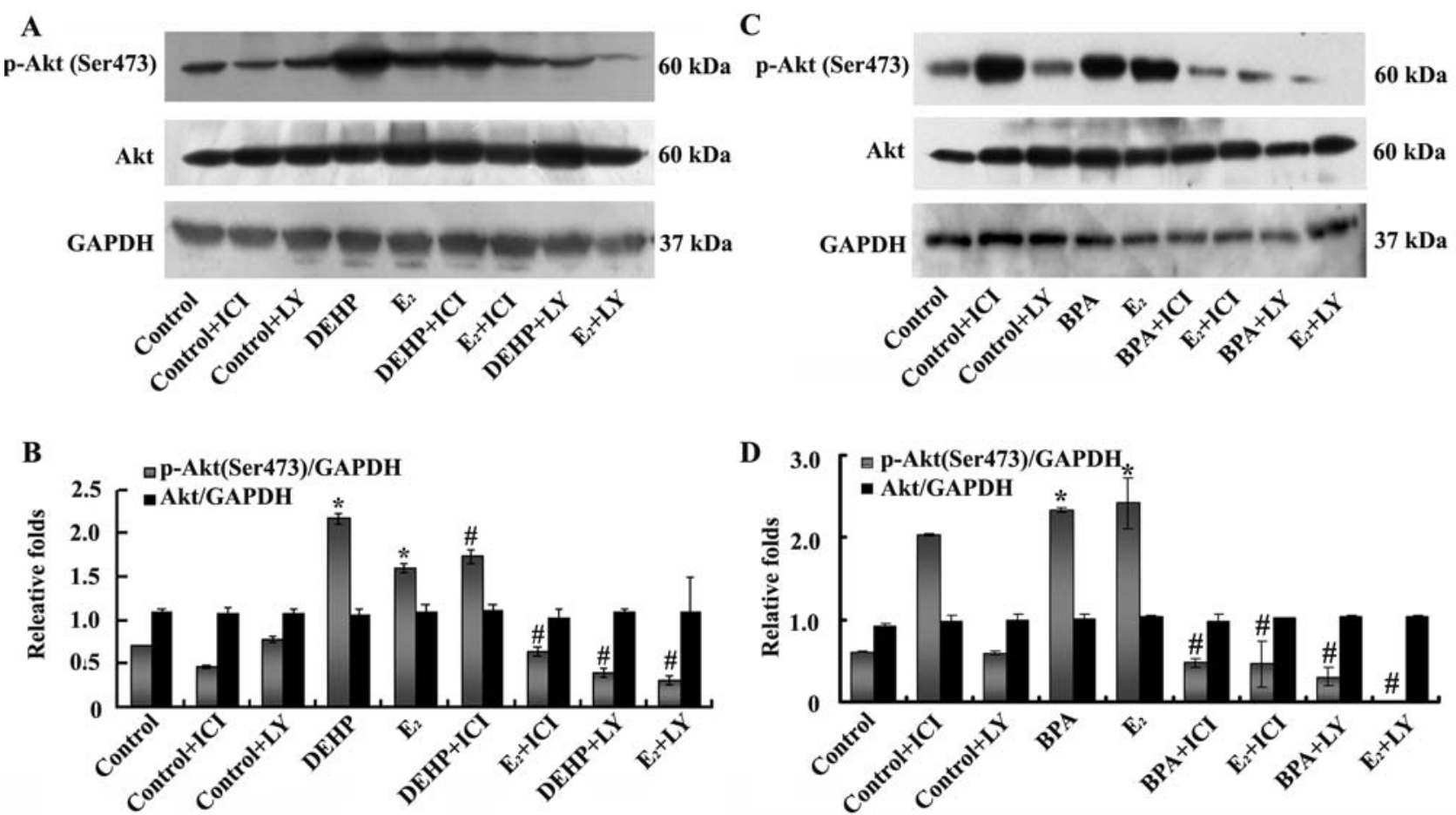

Figure 8. phospho-Akt-Ser473 (p-AktSer473) and Akt protein expression in human neuroblastoma SK-N-SH cells after 24-h treatments. Cells were treated with DEHP, BPA, or $\mathrm{E}_{2}$ with or without ICI182,780 (ICI, $10 \mu \mathrm{M}$ ) or LY294002 (LY, $20 \mu \mathrm{M}$ ). p-Akt (Ser473) and Akt protein expression were detected by Western blot analysis. Equal loading was confirmed by Western blotting probed with an anti-GAPDH antibody. The mean protein expression (normalized to GAPDH protein expression) in each group was calculated from three dependent experiments. (A) Representative images of p-Akt (Ser473) and Akt protein expression in groups treated with DEHP, $\mathrm{E}_{2}$ or solvent only with or without ICI or LY. (B) The quantitative evaluation histogram of p-Akt (Ser473) and Akt protein expression in groups treated with DEHP, $\mathrm{E}_{2}$ or solvent only with or without ICI or LY. (C) Representative images of p-Akt (Ser473) and Akt protein expression in groups treated with BPA, $\mathrm{E}_{2}$ or solvent only with or without ICI or LY. (D) The quantitative evaluation histogram of p-Akt (Ser473) and Akt protein expression in groups treated with DEHP, $\mathrm{E}_{2}$ or solvent only with or without ICI or LY. All quatitative data are presented as mean \pm SEM. ("P $<0.01$, vs. the control group; ${ }^{\#} \mathrm{P}<0.01$, vs. the DEHP, BPA, or $\mathrm{E}_{2}$ group, respectively).

had lower capacity of invasiveness after exposure to DEHP, BPA, or $E_{2}(119.40 \pm 7.50$ and $75.60 \pm 6.60,121.80 \pm 13.50$ and $74.40 \pm 6.00,122.80 \pm 8.70$ and $70.40 \pm 4.40$, respectively) than cells treated with DEHP, BPA, or $\mathrm{E}_{2}$ only $(298.60 \pm 18.40$, $342.40 \pm 6.70$, and 347.60 \pm 3.90 , respectively; $\mathrm{P}<0.001$; Fig. 5A and $\mathrm{B})$.

Furthermore, DEHP, BPA or $\mathrm{E}_{2}$ exposure was not able to enhance MMP-2 and MMP-9 mRNA as well as protein expression in groups pretreated with ICI182,780 or LY294002. Compared with the DEHP, BPA or $\mathrm{E}_{2}$-only treatment group, the groups treated with both DEHP, BPA, or $E_{2}$ and ICI182,780 or LY294002 had (7.53 \pm 1.18 and $22.48 \pm 1.82),(7.52 \pm 1.69$ and $23.56 \pm 1.63)$ and $(6.73 \pm 1.68$ and 29.72 \pm 0.81$)$ times lower MMP-2 mRNA expression, respectively $(\mathrm{P}<0.001$; Fig. $6 \mathrm{~A})$. Lower MMP-2 protein expression was observed in the groups treated with both DEHP, BPA, or $\mathrm{E}_{2}$ and ICI182,780 or LY294002 as well $(0.702 \pm 0.068$ and $0.661 \pm 0.040,0.744 \pm 0.095$ and $0.652 \pm 0.071,0.688 \pm 0.024$ and $0.762 \pm 0.027$, respectively) compared with the groups treated with DEHP, BPA or $\mathrm{E}_{2}$ only $(1.348 \pm 0.035,1.301 \pm 0.050$, and $1.485 \pm 0.040$, respectively; $\mathrm{P}<0.01$; Fig. $7 \mathrm{~A}$ and $\mathrm{C}$ ). MMP-9 mRNA expression in the DEHP, BPA and $\mathrm{E}_{2}$ groups pretreated with ICI182,780 or LY294002 were also $(2.08 \pm 0.66$ and $23.13 \pm 0.11),(2.58 \pm 1.44$ and $23.04 \pm 0.10)$ and $(4.66 \pm 1.05$ and 38.72 \pm 0.13 ) times lower than those in the groups treated with DEHP, BPA or $\mathrm{E}_{2}$ only, respectively $(\mathrm{P}<0.001$; Fig. 6B). Lower levels of MMP-9 protein were still observed in the groups with both DEHP, BPA or $\mathrm{E}_{2}$ and ICI182,780 or LY294002 treatments $(0.515 \pm 0.005$ and $0.317 \pm 0.086$, $0.494 \pm 0.014$ and $0.374 \pm 0.095,0.488 \pm 0.057$ and $0.371 \pm 0.052$, respectively) compared with the DEHP, BPA or $\mathrm{E}_{2}$-only treatment group $(1.104 \pm 0.002,1.223 \pm 0.010$, and $1.042 \pm 0.034$, respectively; $\mathrm{P}<0.01$, Fig. 7A and $\mathrm{B}$ ). On the contrary, TIMP-2 mRNA levels in the groups treated with both DEHP, BPA, or $\mathrm{E}_{2}$ and ICI182,780 or LY294002 were $(41.85 \pm 2.34$ and $195.12 \pm 10.99),(35.66 \pm 3.63$ and $206.34 \pm 12.83)$ and $(200.67 \pm 8.14$ and $504.83 \pm 10.91)$ times higher than the DEHP, BPA, or $\mathrm{E}_{2}$ group without the IC182,780 or LY294002 treatment, respectively $(\mathrm{P}<0.001$; Fig. $6 \mathrm{C})$. TIMP-2 protein levels were also significantly higher in both DEHP, BPA or $E_{2}$ and ICI182,780 or LY294002-treated groups than those in the DEHP, BPA or $\mathrm{E}_{2}$-only treatment group $(0.446 \pm 0.015$ and $0.300 \pm 0.124$ vs. $0.133 \pm 0.005,0.432 \pm 0.049$ and $0.377 \pm 0.052$ vs. $0.110 \pm 0.013,0.485 \pm 0.055$ and $0.371 \pm 0.032$ vs. 0.174 \pm 0.005 , respectively; $\mathrm{P}<0.05$; Fig. 7A and D).

Moreover, the elevated phosphorylation level of $\mathrm{Akt}$ (Ser473) could not be induced by DEHP, BPA or $\mathrm{E}_{2}$ exposure in the groups pretreated with either ICI182,780 or LY294002 (Fig. 8A and C). Densitometry analysis showed that phos- 
phorylation of Akt (Ser473) in both DEHP or BPA and ICI182,780 or LY294002 treated groups were obviously lower than those in the only DEHP or BPA-treated group $(1.745 \pm 0.079$ and $0.402 \pm 0.061$ vs. $2.176 \pm 0.065,0.478 \pm 0.056$ and $0.306 \pm 0.109$ vs. $2.337 \pm 0.037$, respectively; $\mathrm{P}<0.01$; Fig. 8B and D). The similar trend was also observed in both $\mathrm{E}_{2}$ and ICI182,780 or LY294002 treated groups $(\mathrm{P}<0.01$, Fig. 8B and D). However, there was no significant change in Akt protein expression in the experimental groups ( $\mathrm{P}>0.05$, Fig. 8$)$.

\section{Discussion}

Neuroblastoma is one of the most common pediatric cancers. It arises from neural crest tissue and can occur anywhere along the sympathetic chain. Mechanisms of cell metastasis which is the most important cause of death in neuroblastoma are still poorly understood. Some studies suggested that genetic variations may contribute to the cell meatstasis in NB (6). Recently, it is reported that the incidence of neuroblastoma is increasing while environmental pollutions are becoming worse, and our previous studies also revealed the relationship between EED and neuroblastoma cell proliferation (24-26,33). Therefore, we further hypothesize that EED are risk factors for NB cell metastasis and they may also be involved with genetic risk factors that are associated with NB metastasis.

The SK-N-SH cell line was established from a 4-year-old female patient with a bone marrow metastasis and SK-N-SH cells show multiple biological properties of neural crest cells in vitro culture $(34,35)$. This cell line is a better in vitro model for studies of the biology of neuroblastoma than other neuroblastoma cell lines (34) and we used this cell line as an in vitro model in our previous studies (24-26). In this study, we first detected neurobastoma metastasis related gene (MMP-2, MMP-9, and TIMP-2) expression in SK-N-SH cells. Both RT-PCR and immunochemistry analysis suggested that MMP-2, MMP-9 and TIMP-2 expression at mRNA and protein levels are detectable. Therefore, this cell line is also useful for neuroblastoma metastasis related studies in vitro. Furthermore, we confirmed SK-N-SH cells were estrogen receptor (ER)- $\beta$ positive but ER $\alpha$ negative cells, which is consistent with results of previous studies (36).

In the current study, we examined effects of DEHP and BPA, two of the most important EED, as well as estrogen $\left(\mathrm{E}_{2}\right)$ on SK-N-SH neuroblastoma cell migration and invasion. In the cell migration and invasion assay, DEHP, $\mathrm{BPA}$ or $\mathrm{E}_{2}$ exposure resulted in higher capacity of the motility or invasiveness in SK-N-SH cells, which implicated that neuro-blastoma cells would be more susceptible to invasion and metastasis. MMPs are a group of zincdependent endopeptidases that are responsible for degrading extracelluar matrix components and play key roles in cancer cell proliferation, invasion, metastasis and angiogenesis (37). MMPs are also involved in neuroblastoma metastasis. Cheng et al found higher levels of MMP-2 and MMP-9 expression, but a lower level of TIMP-2 expression in metastatic neuroblastoma than those in neuroblastoma without metastasis (29). Moreover, an increased production of MMP-2 and MMP-9 induced angiogenesis in neuroblastoma and enhanced tumor dissemination (38). Therefore, we further investigated whether exposure to DEHP, BPA or $\mathrm{E}_{2}$ affect the MMP-2, MMP-9 or TIMP-2 expression. As revealed by real-time PCR and Western blot analysis, all these drugs could upregulate the expression of MMP-2 and MMP-9, and downregulate the expression of TIMP-2. The results demonstrated that $\mathrm{DEHP}, \mathrm{BPA}$ and $\mathrm{E}_{2}$ promote neuroblastoma cell invasion and metastasis in vitro.

It has been reported that EED as well as $\mathrm{E}_{2}$ mainly exert their estrogenic effects through classic ER-dependent pathway (30-32). ER $\alpha$ and ERß, encoded by ESR1 and ESR2 gene, respectively, are the main ER subtypes (39). ICI182,780 is a specific ER antagonist and has an ability to block ER-dependent biologic effects (40). In the current study, ICI182,780 treatment effectively abolished DEHP, BPA, and $\mathrm{E}_{2}$-induced cell migration and invasion, and significantly blocked DEHP, BPA, or $\mathrm{E}_{2}$-induced upregulation of MMP-2 and MMP-2 expression as well as downregulation of TIMP-2 expression. It suggested that EED and $\mathrm{E}_{2}$ promote neuroblastoma cell invasion and metastasis through ER-dependent pathway and ICI182,780 may be a new potential drug for improved neuroblastoma therapies. In addition, we demonstrated that EED and $\mathrm{E}_{2}$ could still exert their biologic effects through ER-dependent pathway in ER $\beta$ positive, ER $\alpha$ negative cells although substantial evidence indicates that ER $\alpha$ played a more important role than ERß in cancer promotion and progression $(31,41-43)$. Therefore, ERß is also strongly associated with $\mathrm{EED}$ or $\mathrm{E}_{2}$ mediated carcinogenesis.

Phosphatidylinositide 3-kinases (PI3Ks) are a group of intracellular lipid kinases that phosphorylate the 3'-hydroxyl group of phosphatidylinositol and phosphonositides (44). $\mathrm{PI} 3 \mathrm{~K}$ and its signaling pathway regulate various processes including cell metabolism, cell cycle and survival, cell apoptosis, and protein synthesis in the body (44). The protein serine/threonine kinase (Akt) is the cellular homolog of $\mathrm{v}$-Akt oncogene and a member of the AGC family of kinases (45). It acts as a principal downstream component of PI3K pathway and the level of its phosphorylation on Ser473 represents the activity of PI3K/Akt signaling pathway. The activity of PI3K pathway can be modified by growth factors, vitamins as well as hormones (45-47). PI3K/Akt pathway deregulation is strongly related to metabolism disorders, mental disease including schizophrenia, and tumorigenesis as well (46-49). Furthermore, PI3K/Akt pathway involved in EED and estrogen biological effects has also been reported $(32,50)$. In our study, DEHP, BPA and $\mathrm{E}_{2}$ also induced Akt (Ser473) phosphorylation and activate the PI3K pathway. Additive LY294002 treatment could block DEHP, BPA and $\mathrm{E}_{2}$ induced $\mathrm{SK}-\mathrm{N}-\mathrm{SH}$ cell migration and invasion as well as MMP-2, MMP-9 and TIMP-2 deregulation. The above evidence indicates that PI3K/Akt pathway is involved in promoting effects of EED and estrogen on neuroblastoma cell invasion and metastasis. Moreover, like LY294002, additive ICI182,780 also resulted in marked reduction in the activity of PI3K/Akt pathway, which demonstrates that inhibition of ICI182,780 on EED and estrogen-mediated cell invasion and metastasis also involves the PI3K/Akt pathway. 
In summary, DEHP, BPA as well as $\mathrm{E}_{2}$ potently promote invasion and metastasis of neuroblastoma cell in vitro. These effects are mediated by ERß and involve the PI3K/Akt pathway. EED including DEHP and BPA or estrogen are novel risk factors for neuroblastoma metastasis. Estrogen receptor and downstream kinases in PI3K pathway will be potential targets for new target therapies for neuroblastoma. Further investigation of the EED impact on neuroblastoma and other childhood cancers is required to improve preventive methods of pediatric tumorigenesis.

\section{Acknowledgements}

This work was supported by grants from the Ph.D. Program Foundation of Ministry of Education of China (No. 20070246014) and the Youth Scientific Research Foundation of Shanghai Health Bureau, China (2007-QN-74). We thank Dr Tiewei Chen of Cancer Hospital of Fudan University for the gift of MCF-7 breast cancer cells, Zhenjue She and Honglei Xiao of Shanghai medical school of Fudan University for technical advice, Dr Yiping Shen of Childen's Hosptial Boston and Harvard Medical School for the help in preparing our manuscript.

\section{References}

1. McHugh K: Renal and adrenal tumours in children. Cancer Imaging 7: 41-51, 2007.

2. Park JR, Eggert A and Caron H: Neuroblastoma: biology, prognosis, and treatment. Pediatr Clin North Am 55: 97-120, 2008 .

3. Maris JM, Hogarty MD, Bagatell R and Cohn SL: Neuroblastoma. Lancet 369: 2106-2120, 2007.

4. Brodeur GM: Neuroblastoma: biological insights into a clinical enigma. Nat Rev Cancer 3: 203-216, 2003.

5. Schwab M, Westermann F, Hero B and Berthold F: Neuroblastoma: biology and molecular and chromosomal pathology. Lancet Oncol 4: 472-480, 2003.

6. Ara T and DeClerck YA: Mechanisms of invasion and metastasis in human neuroblastoma. Cancer Metastasis Rev 25: 645-657, 2006

7. Vandenberg LN, Hauser R, Marcus M, Olea N and Welshons WV: Human exposure to bisphenol A (BPA). Reprod Toxicol 24: 139-177, 2007.

8. Makey CM, Rubin BS, Soto AM and Sonnenschein C: Endocrine disruptors: from Wingspread to environmental developmental biology. J Steroid Biochem Mol Biol 83: 235-244, 2002.

9. Mello-da-Silva CA and Fruchtengarten L: Environmental chemical hazards and child health. J Pediatr 81: S207-S211, 2005.

10. Vom Saal FS and Myers JP: Bisphenol A and risk of metabolic disorders. JAMA 300: 1353-1355, 2008.

11. Hotchkiss AK, Rider CV, Blystone CR, et al: Fifteen years after 'Wingspread'-environmental endocrine disrupters and human and wildlife health: where we are today and where we need to go. Toxicol Sci 105: 235-259, 2008.

12. Schoeters G, Den Hond E, Dhooge W, van Larebeke N and Leijs M: Endocrine disruptors and abnormalities of pubertal development. Basic Clin Pharmacol Toxicol 102:168-175, 2008.

13. Prins GS: Endocrine disruptors and prostate cancer risk. Endocr Relat Cancer 15: 649-656, 2008.

14. Gray J, Evans N, Taylor B, Rizzo J and Walker M: State of the evidence: the connection between breast cancer and the environment. Int J Occup Environ Health 15: 43-78, 2009.

15. Hauser R and Calafat AM: Phthalates and human health. Occup Environ Med 62: 806-818, 2005.

16. Palanza P, Gioiosa L, vom Saal FS and Parmigiani S: Effects of developmental exposure to bisphenol A on brain and behavior in mice. Environ Res 108: 150-157, 2008.
17. Maffini MV, Rubin BS, Sonnenschein C and Soto AM: Endocrine disruptors and reproductive health: the case of bisphenol-A. Mol Cell Endocrinol 254-255: 179-186, 2006.

18. Richeter CA, Birnbaum LS, Farabollini F, et al: In vivo effects of bisphenol A in laboratory rodent studies. Reprod Toxicol 24: 199-224, 2007.

19. Swan SH: Environmental phthalate exposure in relation to reproductive outcomes and other health endpoints in humans. Environ Res 108: 177-184, 2008.

20. Latini G, Del Vecchio A, Massaro M, Verrotti A and De Felice C: Phthalate exposure and male infertility. Toxicology 226: 90-98, 2006.

21. Lang IA, Galloway TS, Scarlett A, Henley WE, Depledge M, Wallace RB and Melzer D: Association of urinary bisphenol A concentration with medical disorders and laboratory abnormalities in adults. JAMA 300: 1303-1310, 2008.

22. Takeshita A, Inagaki K, Igarashi-Migitaka J, Ozawa Y and Koibuchi N: The endocrine disrupting chemical, diethylhexyl phthalate, activates MDR1 gene expression in human colon cancer LS174T cells. J Endocrinol 190: 897-902, 2006.

23. Buteau-Lozano H, Velasco G, Cristofari M, Balaguer P and Perrot-Applanat M: Xenoestrogens modulate vascular endothelial growth factor secretion in breast cancer cells through an estrogen receptor-depenedent mechanism. J Endocrinol 196: 399-412, 2008.

24. Zheng J, Xiao X, Liu J, Zheng S, Yin Q and Yu Y: Growthpromoting effect of environmental endocrine disruptors on human neuroblastoma SK-N-SH cells. Environ Toxicol Phar 24: 189-193, 2007.

25. Zhu H, Xiao X, Zheng J, Zheng S, Dong K and Yu Y: Growthpromoting effect of bisphenol A on neuroblastoma in vitro and in vivo. J Pediatr Surg 44: 672-680, 2009.

26. Zhu H, Xiao X, Zheng J, Zhou G and Wang Y: Growthpromoting effect of di-2-ethylhexyl phthalate on human neuroblastoma cells. Fudan Univ J Med Sic 36: 407-412, 2009.

27. Papoutsi Z, Zhao C, Putnik M, Gustafsson JA and DahlmanWright K: Binding of estrogen receptor $\{$ alpha $\} /\{$ beta $\}$ heterodimers to chromatin in MCF-7 cell. J Mol Endocrinol 43: 65-72, 2009.

28. Duffy MJ and McCarthy K: Matrix metalloproteinases in cancer: prognostic markers and targets for therapy. Int J Oncol 12: 1343-1348, 1998.

29. Cheng Y, Dong Q, Sun LR, Yang CM and Jiang BX: Correlation between expression of MMP-2, MMP-9, TIMP-2, TIMP-1 and metastasis of neuroblastoma. Zhonghua Zhong Liu Za Zhi 27: 164-166, 2005.

30. Dang VH, Nguyen TH, Lee GS, Choi KC and Jeung EB: In vitro exposure to xenoestrogens induces growth hormone transcription and release via estrogen receptor-depedent pathways in rat pituitary GH3 cells. Steroids 74: 707-714, 2009.

31. Park SH, Kim KY, An BS, Choi JH, Jeung EB, Leung PC and Choi KC: Cell growth of ovarian cancer cells is stimulated by xenoestrogens through an estrogen-dependent pathway, but their stimulation of cell growth appears not to be involved in the activation of the mitogen-activated protein kinases ERK-1 and p38. J Reprod Dev 55: 23-29, 2009.

32. Welshons WV, Nagel SC and vom Saal FS: Large effects from small exposures. III. Endocrine mechanisms mediating effects of bisphenol A at levels of human exposure. Endocrinology 147: S56-S69, 2006.

33. Dalmasso P, Pastore G, Zuccolo L, Maule MM, Pearce N, Merletti F and Magnani C: Temporal trends in the incidence of childhood leukemia, lymphomas and solid tumors in northwest Italy, 1967-2001. A report of the childhood cancer registry of piedmont. Haematologica 90: 1197-1204, 2005.

34. Maggi R, Poletti A, Casulari LA, Pimpinelli F, Piva F, Zanisi MR and Martini L: Effects and metabolism of steroid hormones in human neuroblastoma cells. Steroids 63: 257-262, 1998

35. Biedler JL, Helson L and Spengler BA: Morphology and growth, tumorigenicity, and cytogenetics of human neuroblastoma cells in continuous culture. Cancer Res 33: 2643-2652, 1973.

36. Ba F, Pang PK, Davidge ST and Benishin CG: The neuroprotective effects of estrogen in SK-N-SH neuroblastoma cell cultures. Neurochem Int 44: 401-411, 2004.

37. Vihinen P, Ala-aho R and Kahari VM: Matrix metalloproteinases as therapeutic targets in cancer. Curr Cancer Drug Targets 5: 203-220, 2005 . 
38. Ribatti D, Marimpietri D, Pastorino F, Brignole C, Nico B, Vacca A and Ponzoni M: Angiogenesis in neuroblastoma. Ann N Y Acad Sci 1028: 133-142, 2004.

39. Ball LJ, Levy N, Zhao X, Griffin C, Tagliaferri M, Cohen I, Ricke WA, Speed TP, Firestone GL and Leitman DC: Cell typeand estrogen receptor-subtype specific regulation of selective estrogen receptor modulator regulatory elements. Mol Cell Endocrinol 299: 204-211, 2009.

40. Yanagihara N, Toyohira Y and Shinohara Y: Insights into the pharmacological potential of estrogens and phytoestrogens on catecholamine signaling. Ann N Y Acad Sci 1129: 96-104, 2008.

41. Ascenzi P, Bocedi A and Marino M: Structure-function relationship of estrogen receptor $\alpha$ and $B$ : impact on human health. Mol Aspects Med 27: 299-402, 2006.

42. Recchia AG, Vivacqua A, Gabriele S, Carpino A, Fasanella G Rago V, Bonofiglio D and Maggiolini M: Xenoestrogens and the induction of proliferative effects in breast cancer cells via direct activation of oestrogen receptor alpha. Food Addit Contam 21: 134-144, 2004.

43. Bolli A, Galluzzo P, Ascenzi P, et al: Laccase treatment impairs bisphenol A-induced cancer cell proliferation affecting estrogen receptor alpha-dependent rapid signals. IUBMB Life 60: 843-852, 2008.
44. Engelman JA, Luo J and Cantley LC: The evolution of phosphatidylinositol-3-kinases as regulators of growth and metabolism. Nat Rev Genet 7: 606-619, 2006.

45. Yoeli-Lerner M and Toker A: Akt/PKB signaling in cancer: a function in cell motility and invasion. Cell Cycle 5: 603-605, 2006.

46. Vivanco I and Sawyers CL: The phosphatidylinositol 3-kinase AKT pathway in human cancer. Nat Rev Cancer 2: 480-501, 2002.

47. Kalkman HO: The role of phosphatidylinositide 3-kinaseprotein kinase B pathway in schizophrenia. Pharmacol Ther 110: 117-134, 2006.

48. Franke TF: PI3K/Akt: getting it right matters. Oncogene 27: 6473-6488, 2008

49. Tokunaga E, Oki E, Egashira A, Sadanaga N, Morita M, Kakeji Y and Maehara Y: Deregulation of the Akt pathway in human cancer. Curr Cancer Drug Targets 8: 27-36, 2008.

50. Vasconsuelo A, Milanesi L and Boland R: 17Beta-estradiol abrogates apoptosis in murine skeletal muscle cells through estrogen receptors: role of the phosphatidylinositol 3-kinase/Akt pathway. J Endocrinol 196: 385-397, 2008. 